\title{
Potentials and Challenges of Existing Plastic Pollutant Biodegradation Using Bacteria in Jakarta Bay
}

\author{
Syarifatun Nisa Nurdhy \\ PT. ITS Science Indonesia, Life Science Division, Sentra Bisnis Artha Gading, \\ Jl. Boulevard Artha Gading, Blok A-6A No. 3 \& 5, Kelapa Gading Barat - Jakarta Utara 14240, Indonesia, \\ Tel. +62-21-4516222, Fax +62-214516223. \\ Email: nisa@its-indonesia.com
}

\begin{abstract}
Research conducted by Research Center for Marine and Fisheries Product Processing and Biotechnology in the three different locations namely Tarakan, Tanjung Balai Asahan, and Jakarta Bay, has identified that Jakarta Bay had the highest plastic debris concentration among the others. Jakarta Bay is directly connected to Thousand Island National Park sea waters, in which large parts of it are marine conservation area. Thus, plastic pollutants potentially threat Jakarta Bay and Thousand Island National Park abundant biodiversity and underwater marine ecotourism. The tools such as garbage transport barges owned by Special Region of the Capital Jakarta Province are not enough to overcome the existing plastic debris. 21 tons waste end up to Jakarta Bay every day. There should be further research about solving existing plastic waste with other technology than using machine. This literature study aims to review and investigate the potentials and challenges of utilizing bacteria to combat existing marine plastic pollution in Jakarta Bay. Established researches showed that some bacteria strains isolated from plastic debris in some sea waters and sediments around the world are capable of degrading polyethylene (PE), polypropylene (PP), and possibly polystyrene (PS). Unfortunately, reports involving plastic degrading ability of bacteria isolated from plastic wastes in Indonesian sea waters, let alone Jakarta Bay, are hard to find if any. There were only researches about isolated bacterias from Jakarta Bay, which were capable of degrading oil spill. Further research about isolated bacteria from plastic debris of Jakarta Bay, should be established. It can be used to identify bacteria strains or consortia that are able to degrade plastic debris with environmentally friendly byproducts. There will be possibilities that oil spill degrading bacteria isolated from Jakarta Bay can also degrade plastics, as both oil spill and plastics are made up from hydrocarbon chains. A recently published research has revealed that Alvoranicus borkumensis isolated from marine plastic debris in Mediterranean Sea was able to degrade PE, while previously other study has isolated it from Thousand Islands sea waters and found it able to degrade marine oil spill. The expression possibility of DNA (deoxyribonucleic acid) sequence coding extracted from wax worm Galleria mellonella into widespread indigeneous Jakarta Bay bacteria and bacteria isolated from plastic debris in Jakarta Bay, can also be taken into account.
\end{abstract}

Keywords: Indonesian sea waters, Jakarta Bay, marine plastic biodegradation, plastic debris, plastic degrading bacteria

\begin{abstract}
Abbreviations: 3R (Reduce, Reuse, Recycle), PE (Polyethylene), PET (Polyethylenephtalat), Polystyrene (PS), Polyvynil (PV), Polyvynil Chloride (PVC), Carbondioxyde $\left(\mathrm{CO}_{2}\right)$, Nitrogen $\left(\mathrm{N}_{2}\right)$, Methane $\left(\mathrm{CH}_{4}\right)$, and water $\left(\mathrm{H}_{2} \mathrm{O}\right)$, LDPE (Low Density Polyethylene), PVA-LLDPE (Polyvinyl Alcohol - Low Linear Density Polyethylene), PHB (Polyhydroxybutyrate), Polycaprolactone (PCL), Polybutylene succinate (PBS), Poly(3-hydroxybutyrate-co-3-hydroxyvalerate) (PHBV), SEM (Scanning Electron Microscope), Polycyclic aromatic hydrocarbons (PAHs), United Kingdom (UK)
\end{abstract}

\section{INTRODUCTION}

Indonesia is the second biggest ocean plastic pollutant contributor in the world after China. Around 3.2 million tons pastic debris per year resulted from activities surround the beach, 0.48-1.29 million ton/year would be accumulated in Indonesian marine environment (Jambeck et al. 2015; Dwiyitno et al. 2018). Research conducted by Research Center for Marine and Fisheries Product Processing and Biotechnology in the 3 different locations namely Tarakan, Tanjung Balai Asahan, and Jakarta Bay, identified that the highest marine debris concentration was found in Jakarta Bay, followed by Tanjung Balai Asahan and Tarakan seawaters. Marine debris identified, were consisted of organic and inorganic waste. The dominant inorganic waste found in Jakarta Bay were food or food condiments packaging, plastic bag, plastic crumbs, soap packaging, plastic cups, plastic cutleries consisted of straw, spoon, fork, and food containers), soft drink bottles and their caps, medicine packaging, strings, nylons, cigarette packaging. In the other hand, organic waste of Jakarta Bay were found in relatively few quantities and variations, such as tree small branches, leaves, and food leftovers.

Based on the types, PE and PP dominated the marine plastic debris of Jakarta Bay, apart from PET, PS and PV that were also identified (Dwiyitno et al. 2018). The plastic debris were found in more than $70 \%$ of 32 sampling points. In Tanjung Balai seawater, plastic debris were found in $50 \%$ of sampling points, while in Tarakan seawater, plastic debris was found only in $30 \%$ sampling points. Highest plastic waste concentration in Jakarta Bay was 2 particles $/ \mathrm{m}^{2}$ or $2 \mathrm{~g} / \mathrm{m}^{2}$ (Dwiyitno et al. 2018).

Microplastic found in Jakarta Bay water and sediment samples were also higher than other areas. The 
highest microplastic concentration found in Jakarta Bay seawater sample was 31 particles $/ \mathrm{m}^{3}$, weighed 130 $\mathrm{mg} / \mathrm{m}^{3}$, while 3 particles $/ \mathrm{kg}$ were found in the sediment, weighed $2.4 \mathrm{mg} / \mathrm{kg}$. Generally, microplastics in Jakarta Bay were found in fragment shapes (Dwiyitno et al. 2018). According to National Oceanic and Atmospheric Administration (2016), microplastics is small plastic pieces less than five millimeters and can be harmful to ocean and aquatic life due to its small size. Sundt, Schulze, dan Syversen (2014) stated that microplastics were categorized into 2 types, primer and secondary microplastics. Primer microplastics were made from micro particles, such as industrial plastic raw material and from cosmectics scrub. Secondary microplastics were made from ocean environment. They came from macroplastics, which were fragmented into smaller pieces due to weathering (Rachmat et al. 2018). According to UNEP (2011), potential impact of marine plastic debris chemically tends to increase as the size of plastic particle decreases to microplastics, while physical effect increases as the macro debris size increases as well (Rachmat et al. 2019). In Jakarta Bay ecosystem, fragment microplastics were found dominantly in the fisheries biota, if compared to non-fragment type. In the other hand, concentration of microplastics in bivalves wer generally higher (up to 50 particles/bivalves) than to those found in the fish (up to 20 particles/fish). Microplastics accumulation in the fish were detected in gill and intestination, but have not identified in meat yet (Dwiyitno et al, 2018).

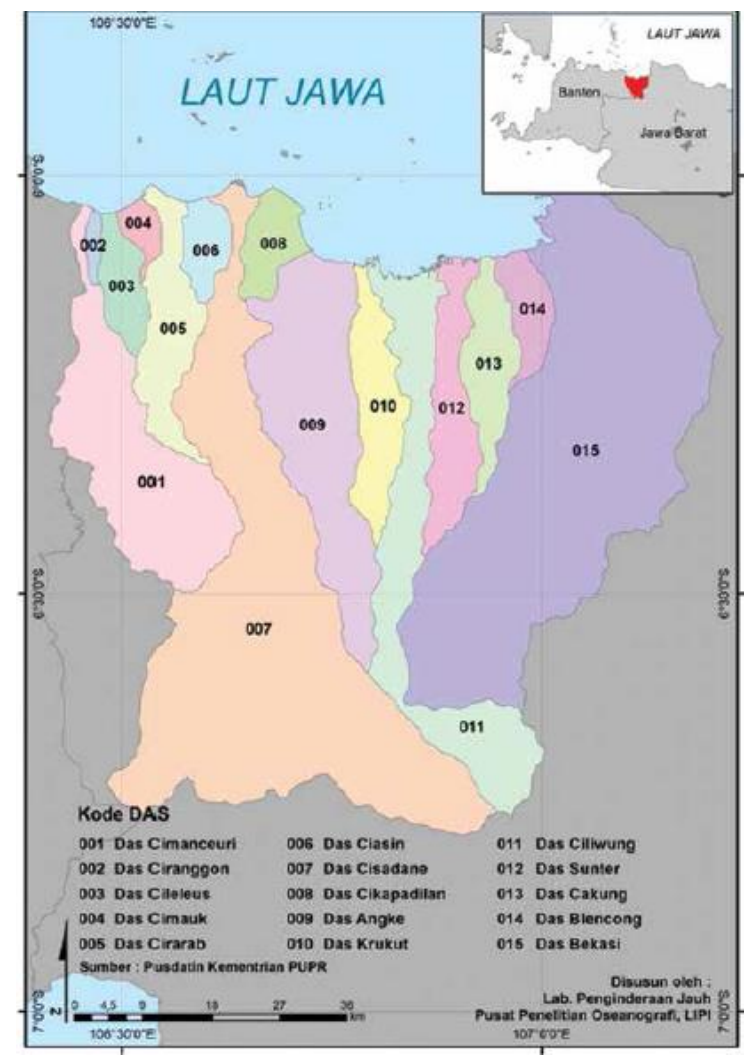

Figure 1. Rivers that flow into Jakarta Bay (Rositasari et al, 2017)
Enormous plastic pollutant quantities in Jakarta Bay is inevitable impact of Jakarta region being metropolitan and Indonesian capital city, which it and its satellite cities have to sustain various industrial sector activities such as mining, transportations, energy, tourisms, and many more. Jakarta Bay is the estuary of 13 rivers and 2 canals flowing from Jakarta, Bekasi, and Tangerang (Figure 1). High industrial activities in Jakarta and its satellite cities caused population bloom which increased waste quantities and environmental burden (Rositasari et al. 2017)

Special Region of the Capital Jakarta Province regional government was overwhelmed in handling this existing plastic waste, stated that its neighboring cities such as Bekasi and Tangerang has not yet had good waste management, which ended up impacting Jakarta Bay in Jakarta area. Therefore, the tools such as garbage transport barges owned by Jakarta are not enough to overcome the existing drifted plastic wastes (Hidayat 2018).

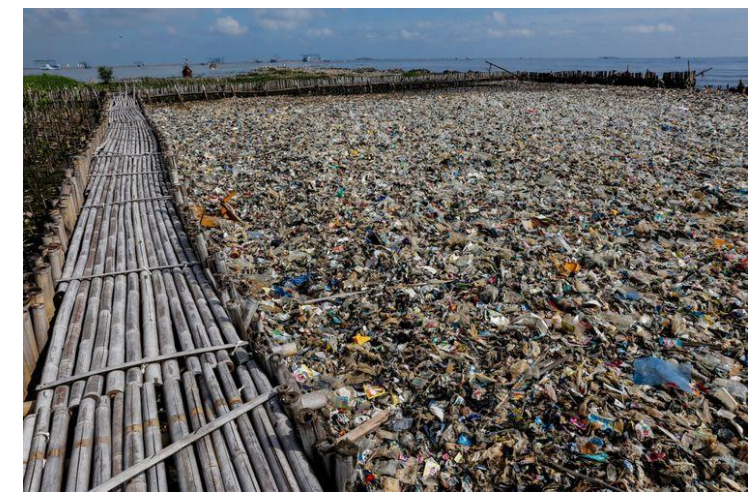

Figure 2. Jakarta Bay plastic waste (Lotulung, 2018)

According to Reza Cordova as scientist from Oceanography Indonesian Science Institute, there has been 21 tons waste ended up to Jakarta Bay every day (Ramadhan 2018). Therefore, there should be further research about solving existing waste with other technology than using machine. Given this situation, this paper aims to review and investigate the potentials and challenges of utilizing bacteria in plastic degradation to combat existing marine plastic pollution in Jakarta Bay.

\section{MATERIALS AND METHODS}

\section{Materials}

The reviewed studies were sourced from mainly scientific papers and journals, and a few news relevant to the following themes, either in Bahasa or English:

- marine plastic waste in Jakarta Bay

- Jakarta Bay ecosystem biodiversity

- threats of marine plastic waste to marine biodiversity

- marine plastic waste biodegradation in Jakarta Bay

- marine plastic waste biodegradation using bacteria 
- marine plastic waste biodegradation using bacteria isolated from marine plastic debris

All sources, whether scientific papers, journals or news, were collected from internet with keywords associated to the previously mentioned themes. The selection was based on:

- Relevant informations of the studies addressing the issues presented by this paper

- Informations that raise important ideas for exploring the results of unanswered issues

- Informations that provide relevant insights for future research directions

\section{Methods}

This review paper used descriptive qualitative method. Descriptive qualitative method is a method to investigate objects that cannot be measured with numbers or other exact measurements, and tend to use analysis with inductive approach (Fachrul and Rinanti, 2018).

\section{DISCUSSION AND RESULTS}

\section{The potential effects of plastic debris in threating ecosystem biodiversity in Jakarta Bay}

Jakarta Bay consists of two (coastal ecosystems), which is Jakarta Bay and Thousand Islands Complex (Arifin 2004). The whole ecosystem, which called Greater Jakarta Bay Ecosystem, stretches from 106 20 'to $107^{\circ} 03^{\prime}$ east longitude, and from $5^{\circ} 10^{\prime}$ to $6^{\circ} 10^{\prime}$ south latitude. It is administratively within three provinces, namely Banten Province, the Special Region of the Capital Jakarta Province, and West Java province (Figure 3). The Jakarta Bay is bordering Tanjung Pasir cape to the west and Tanjung Karawang cape to the east. It is mainly influenced by land-based activities. On the other hand, Thousand Islands Complex forms a chain stretching along 80 kilometers from a northwest to southeast line. It is a coastal ecosystem dominated by 110 small islands. The total land area of the islands is estimated 864,59 ha, with $45 \%$ of the islands have area less than 5 ha, $25 \%$ of them have size $5-10$ ha, and $30 \%$ of the islands has size larger than 10 ha (BAPEKAB Kepulauan Seribu, 2002; Arifin 2004).

Thousand Islands complex has averagely shallow beach flat and protected sea characteristic, with typical barrier reef and reef flat, also lagoon. It is ecologically inseparable from Jakarta Metropolitan area (Atmaja, 2011). Therefore, Jakarta bay sea waters quality affects the quality of Thousand Islands sea water, especially to its parts that located close to Jakarta Bay (Estradivari et al, 2009).

Jakarta Bay itself is home for abundant varieties of coral reefs, Echinodermata, crustaceans, snails, and bivalves, based on research conducted on 1978-1979 by Indonesian Oceanography Institute. Furthermore, a research carried on 2011 by Indonesian Oceanography
Research Center has discovered that Jakarta Bay area was spawning and nursery ground for nine types of stingrays despite its bad water quality (Rositasari et al. 2017). It is also one of important crab fishing area in Java north coast (Sumiono et al. 2011). Green mussel Perna viridis is widely cultivated in this region as well (Nuraini et. al, 2011; Kusnoputranto et al, 2014). In addition, Jakarta Bay seawaters have quite high shrimp production resource. Its estuary area also becomes nursery ground, feeding ground, and spawning ground for various varieties of shrimps, especially from Penaeidae family (Nastiti et al. 2011). Beside of that, Thousand Island National Park complex is one of conservation area for hawksbill turtle (Eremochelys imbricata). Currently, 7 islands are still visited by the sea turtles to lay their eggs on at particular seasons. Pramuka island as part of Thousand Island National park complex, has hawksbill sea turtle (Eremochelys imbricata) and green sea turtle (Chelonia mydas) breeding center (Balai Taman Nasional Kepulauan Seribu 2011; Suhery et al. 2017). Suhery et al (2017) also observed that sea turtles were found in Pramuka Island and Panggang Island. Belanda Island, which is included in the core zone III of the Thousand Islands National Park area, covering an area of 570 hectares, is the conservation area of Hawksbill sea turtle (Eretmochelys imbricata) and coral reefs ecosystem. Apart from sea turtles, species that are protected from the group of marine mammals (cetaceans) namely dolphins, are also identified in the Thousand Islands National Park area (Wardiatno et al. 2010; Suhery et al. 2017). Statement of the Minister of Agriculture at the Third World National Park Congress in 1982 in Bali, Number 736 / Mentan / X / 1982 dated October 10, 1982, declared the Thousand Island National Marine Conservation, covering an area of 108,000 hectares, as the Thousand Islands National Marine Park (Suraji et al. 2015).

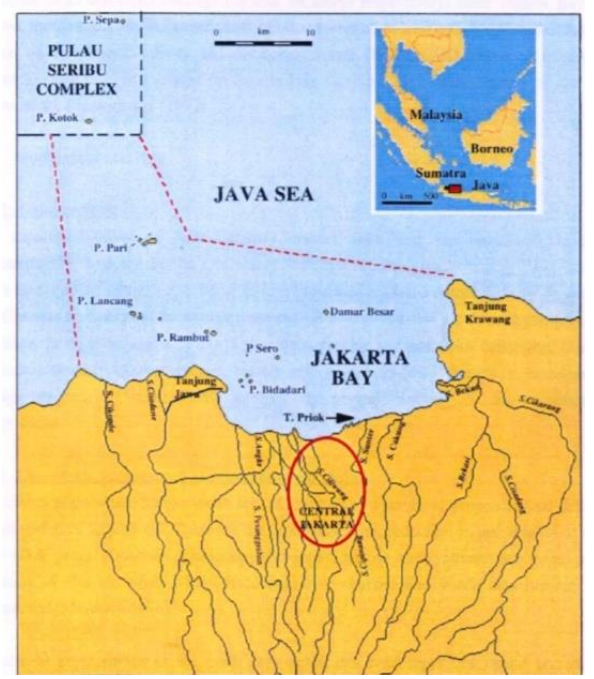

Figure 3. Greater Jakarta Bay ecosystem consists of two coastal ecosystem, namely Jakarta Bay and Thousand Islands Complex (Williams et al, 2000) 
The abundant biodiversity in Greater Jakarta Bay ecosystem is in endangered situation if high accumulated existing plastic waste in Jakarta Bay remains unsolved. Plastic as marine debris can block mangrove roots which can cause mangrove slowly dies of it. Mangrove existence is important for marine ecosystem due to its ability to decompose toxic in the marine environment (Asia and Arifin 2017). There is also a concern that plastic is a source of toxic chemicals such as polychlorinated biphenyls or phthalates and bisphenol A (Bryant et al. 2016; Urbanek et al. 2018). Consequently, the decreasing amount of mangrove will slowly harm other living organisms and ecosystems in the ocean. Plastic debris also can kill coral reefs (Asia and Arifin, 2017), which can have adverse effects for Jakarta Bay and Thousand Island National park complex as the home and conservation area for various coral reefs. Inhabitant communities in some islands in Thousand Islands National Park complex such as Pramuka Island, utilize coral reefs in various ways, including as ecotourism object (Suhery et al. 2017). Apart from that, mangrove ecosystem is one of coastal area ecosystems that potentially trap the debris due to its location. Mangrove forest is adjacent to both land and ocean. Mangrove also has root morphology that can trap the debris in huge amount. This macro plastic debris accumulation on the mangrove forest potentially disrupts the ecosystem stability. One of ecology roles of mangrove in coastal area is as habitat for other organisms, such as fishes, crustaceans. Therefore, macro debris accumulation in mangrove forest will disrupt the survival of many organisms who live in it (Maharani et al, 2017). Large ocean animals such as fishes, dolphins, turtles, and seals can mistakenly ingest the plastic bags as foods. Consequently, their inability to digest plastics can cause them to die (Asia and Arifin 2017). Entanglement of marine species in marine debris is also a global problem affecting at least 200 species (National Oceanic and Atmospheric Administration 2014). Marine fauna suffocation can also happen due to plastic waste (Derraik 2002; Urbanek 2018). There was a report of three turtles died floating in Pari Island seawaters, as a part of Thousand Islands complex and located close to Jakarta Bay waters. The turtles were suspected dying to oil spill and plastic waste from Jakarta Bay. Plastic debris were found in their mouth and between their front legs (Zuraya 2018). As turtle is one of the protected animals in Thousand Islands National Park, this report is one of the representations that plastic potentially endanger Jakarta Bay ecosystem biodiversity. While large plastic particles affect fish and birds, depending on concentration, pieces of microplastics can represent a threat to organisms at lower trophic levels (Rummel et al. 2017) such as zooplankton and mussels (Caruso 2015).
Marine plastic pollutant biodegradation using bacteria isolated from marine plastic debris

This sub chapter only discusses plastic degradation using bacteria isolated from marine plastic debris, as this paper aims to solve the existing plastic waste problem in Jakarta Bay. Jakarta Bay is part of marine environment. Thus, plastic biodegradation using bacteria sampled from soil, fresh water, or terrestrial environment could be irrelevant due to different environmental factors (Urbanek et al. 2018). Not all bacteria from terrestrial or fresh water environment can survive saline environment (Debroas et al. 2017). Apart from that, this section only reviews bacteria isolated from plastic debris because microbial communities found in plastic debris, which recently are recognized as plastisphere communities, are often distinct from surrounding surface water microbial communities. It implies that plastic serves as a novel ecological habitat in the open ocean (Zettler et al. 2013). Thus, these communities might have different potential effects for plastic waste degradation than bacteria or consortia isolated from surrounding waters.

The abundance of microorganisms in marine ecosystems reaches up to hundreds of millions of bacterial cells in a gram of wet marine sediment (Harrison et al. 2011; Urbanek et al. 2018). It is assumed that any surface in the marine environment is colonized with macro and microorganisms (Eich et al. 2015; Urbanek et al. 2018). Attachment to surfaces and biofilm development are a well-known strategy of bacteria for surviving a variety of conditions in the marine environment (Junge et al. 2004; Urbanek et al 2018), including the ability to form stable consortia, horizontal gene exchange, accumulation of nutrients, and protection against toxic substances (Rummel et al. 2017; Urbanek et al, 2018).

In seawater, bacterial colonization on plastic material starts almost immediately. Within a few hours, microorganisms are able to form microbial assemblages and cover the surface of plastic, which is defined as attachment. During this stage, microbial assemblages might catalyze metabolic reactions that lead to the adsorption, desorption, and fragmentation of microplastic-associated compounds or even the breakdown of the debris itself (Harrison et al. 2011; Urbanek et. al, 2018).

Plastic biodegradation is a process that results in total or partial conversion of organic carbon into biogas and biomass associated with the activity of a community of microorganisms (bacteria, fungi, and actinomycetes) capable of using plastic as a carbon source (Shah et al., 2008; Jacquin et.al, 2019). Depending on the respiratory conditions (aerobic/anaerobic) and the microorganisms involved, the biogas will be different (Mohee et al. 2008; Jacquin et.al, 2019). Biodegradation is considered to occur after or concomitant with physical and chemical degradation, which weakens the structure of polymers as revealed by roughness, cracks and molecular changes 
(Ipekoglu et al., 2007; Jacquin et.al, 2019). Alteration of plastic properties due to abiotic degradation is called "aging" and in nature depends on several factors such as temperature, solar light and chemicals that enhance the rate of degradation by oxidizing or disrupting the length of the polymer chain. Biodegradation can be summarized in four detailed essential steps:

- Bio-deterioration relates to the biofilm growing on the surface and inside the plastic, which increases the pore size and provokes cracks that weaken the physical properties of the plastic (physical deterioration) or releases acid compounds that modify the $\mathrm{pH}$ inside the pores and results in changes in the microstructure of the plastic matrix (chemical deterioration).

- Bio-fragmentation corresponds to the action of extracellular enzymes (oxygenases, lipases, esterases, depolymerases and other enzymes that may be as diverse as the large spectrum of polymer types) released by bacteria colonizing the polymer surface. These enzymes will reduce the molecular weight of polymers and release oligomers and then monomers that can be assimilated by cells.

- Assimilation allows oligomers of less than 600 Daltons to be integrated inside the cells to be used as a carbon source, thus increasing the microbial biomass.

- Mineralization is the ultimate step in the biodegradation of a plastic polymer and results in the excretion of completely oxidized metabolites $\left(\mathrm{CO}_{2}\right.$, $\mathrm{N}_{2}, \mathrm{CH}_{4}$, and $\mathrm{H}_{2} \mathrm{O}$ ) (Dussud and Ghiglione, 2014: Jacquin et al.,2019).

Additionally, various factors related to environmental conditions such as salinity, temperature, oxygen level, and limitation of light have an impact on biofilm development (Dash et al. 2013; De Tender et al. 2015; Urbanek et. al, 2018). Particularly, the increase in degradation rate by raising the temperature and humidity may be crucial. Different variations in sea temperature are expected to affect the rate of plastic degradation due to acceleration or inhibition of chemical reactions (O'Brine and Thompson 2010; Urbanek et al. 2018). Hence, the biomass of a fouling community influenced by different surface characteristics and environmental conditions (Pauli et al. 2017) is not always the same (Urbanek et al. 2018). It was suggested that bacterial adhesion to the plastic surface depends on the physicochemical surface and bacterial properties rather than on biological processes (Artham et al. 2009;
Urbanek et al. 2018). At the same time, biotic and abiotic factors have an influence on released products (van Sebille et al. 2016; Urbanek et al, 2018).

Degradation mechanisms in the marine environment are unfortunately still not clear (Urbanek et al. 2018). However, it was noted that even though bacteria can easily colonize plastic, there is no evidence of potential degradation during early attachment (Lobelle and Cunliffe 2011; Urbanek et al. 2018). Lobelle and Cunliffe (2011) noted that biofilm formation may be visible within 1 week. The hydrophobic features of polyethylene plastic food bags submerged at the sea-end of Queen Anne's Battery (UK) changed during an experiment lasting 3 weeks, but they did not observe polyethylene-degrading organisms. It might be caused by considerably too short research period. Additionally, their study shows that removing the visible biofilm from plastic reverses its physicochemical properties (Lobelle and Cunliffe 2011; Urbanek et al. 2018). In a recent study, biofilm formation on PS and PE was investigated (Oberbeckmann et al. 2017). It was found that already after 2 weeks of incubation in cold marine water (coastal Baltic Sea) microplastics were covered by assemblages, and bacteria from the genus Erythrobacter were found on the microplastics. Bacteria from this genus are known for their ability to utilize polycyclic aromatic hydrocarbons PAHs, though there were no further observations regarding degradation (Oberbeckmann et al. 2017; Urbanek et al, 2018).

Even though some microorganisms are capable of degrading plastic, usually biodegradation is recognized to be low (Debroas et al. 2017; Urbanek et al., 2018). Most studies about marine plastic degrading microorganism, that involved plastic degradation observation in the study, isolated the microorganisms from sea water or sediment (Table 3). However, small number of studies involved bacteria isolation from marine plastic debris, also incorporated the degradation observation in the study. Table 1 presents some literatures that indicated the plastic degradation capability of some bacteria isolated from marine plastic debris, with visible plastic physical alteration or biodegradation observation in the study. This section also provides the list of some studies about bacteria isolation from marine plastic debris, or from plastic that soaked in seawater environment, that potentially able to degrade plastic although the studies did not observe the visible biodegradation further (Table 2) 
Table 1. Plastic degradation capability of some bacteria isolated from marine plastic debris in sea water or sediment, with visible plastic physical alteration or biodegradation in the study

\begin{tabular}{|c|c|c|c|}
\hline Microorganisms & Sources & $\begin{array}{l}\text { Degraded } \\
\text { plastics type }\end{array}$ & References \\
\hline Alcanivorax borkumensis & $\begin{array}{l}\text { PP and PVC collected from Corsica, } \\
\text { Mediterranian sea waters and } \\
\text { sediment respectively }\end{array}$ & LDPE & $\begin{array}{l}\text { Delacuvellerie } \\
\text { et al (2019) }\end{array}$ \\
\hline $\begin{array}{l}\text { Numerous bacteriums forming "plastisphere communities" } \\
\text { including some recognized hydrocarbon degrading bacteria } \\
\text { Phormidium sp.,Pseudoalteromonas, Hyphomonadacea }\end{array}$ & $\begin{array}{l}\text { PP and PE collected from North } \\
\text { Atlantic Subtropical Gyre }\end{array}$ & $\mathrm{PP}$ and $\mathrm{PE}$ & $\begin{array}{l}\text { Zettler et al } \\
(2013)\end{array}$ \\
\hline
\end{tabular}

Table 2 Bacteria isolated from marine plastic debris, or from plastic soaked in marine environment, which were potentially able to degrade plastic though the studies did not observe the biodegradation further

\begin{tabular}{llll}
\hline Microorganisms & Sources & $\begin{array}{l}\text { Potential plastics } \\
\text { type to degrade }\end{array}$ & References \\
\hline Rhodobacteraceae, Alcanivoraceae & $\begin{array}{l}\text { PET drinking } \\
\text { bottles submerged in the North Sea } \\
\text { off the UK coast }\end{array}$ & PE & Oberbeckmann et al (2016) \\
\hline Pseudomonas $s p$. & $\begin{array}{l}\text { PE collected from Corsica, } \\
\text { Mediterranian sea waters }\end{array}$ & PS & Delacuvellerie et al (2019) \\
\hline
\end{tabular}

Table 3. Lists of bacteria sampled from marine environment showed capability to degrade plastic

\begin{tabular}{|c|c|c|c|}
\hline Microorganisms & Sources & Plastics type & References \\
\hline $\begin{array}{l}\text { Shewanella, Moritella sp., Psychrobacter sp., } \\
\text { Pseudomonas sp. }\end{array}$ & $\begin{array}{l}\text { Deep-sea sediment, the } \\
\text { Kurile and Japan } \\
\text { Trenches }\end{array}$ & PCL & $\begin{array}{l}\text { Sekiguchi et al. (2010); Urbanek et. } \\
\text { al. (2018) }\end{array}$ \\
\hline Vibrio alginolyticus, Vibrio parahemolyticus & $\begin{array}{l}\text { Benthic zones of marine } \\
\text { environments }\end{array}$ & PVA-LLDPE & $\begin{array}{l}\text { Raghul et al. (2014); Urbanek et. al. } \\
\text { (2018) }\end{array}$ \\
\hline $\begin{array}{l}\text { Pseudomonas sp., Alcanivorax sp., } \\
\text { Tenacibaculum sp. }\end{array}$ & $\begin{array}{l}\text { Deep seawater of Rausu, } \\
\text { Kume and Toyama bay }\end{array}$ & $\begin{array}{l}\text { Monofilament } \\
\text { fibers of PCL, } \\
\text { PHB/ }, \text { PBS }\end{array}$ & $\begin{array}{l}\text { Sekiguchi et al. (2011); Urbanek et. } \\
\text { al. (2018) }\end{array}$ \\
\hline Bacillus subtilis H1584 & $\begin{array}{l}\text { pelagic waters, Arabian } \\
\text { Sea, India. }\end{array}$ & $\mathrm{PE}$ & $\begin{array}{l}\text { Harshvardhan and Jha (2013); } \\
\text { Jacquin et.al, } 2019\end{array}$ \\
\hline Bacillus pumilus $M 27$ & $\begin{array}{l}\text { pelagic waters, Arabian } \\
\text { Sea, India. }\end{array}$ & $\mathrm{PE}$ & $\begin{array}{l}\text { Harshvardhan and Jha (2013); } \\
\text { Jacquin et.al, } 2019\end{array}$ \\
\hline Kocuria palustris M16 & $\begin{array}{l}\text { pelagic waters, Arabian } \\
\text { Sea, India. }\end{array}$ & $\mathrm{PE}$ & $\begin{array}{l}\text { Harshvardhan and Jha (2013); } \\
\text { Jacquin et al (2019) }\end{array}$ \\
\hline Pseudomonas stutzeri & Jogashima seawater & PHB & $\begin{array}{l}\text { Uefuji et al.(1997); Martínez-Tobón } \\
\text { et al.(2018); Jacquin et al (2019) }\end{array}$ \\
\hline
\end{tabular}

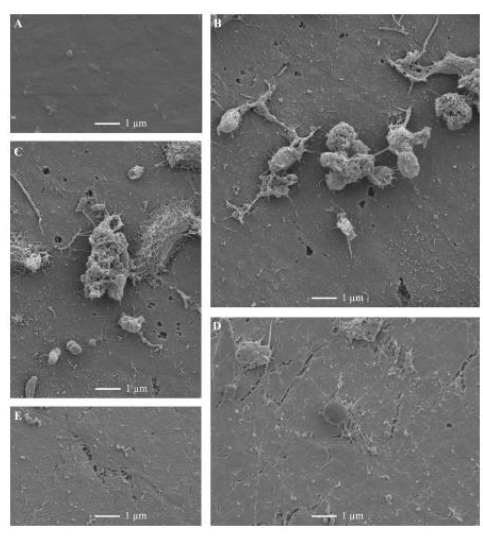

Figure 4. Scanning electron microscopy images of the LDPE surface after two months of enrichment. (A) The negative control (NC) was immersed for 2 months in medium without bacteria. The other pictures show biofilm on LDPE: (B \& C) PFS4 LDPE and (D \& E) PH4 LDPE. Some degradation signs can be observed. The NC does not contain these deformations (Delacuvellerie et al, 2019).
Delacuvellerie et al (2019) found that Alcanovirax borkumensis isolated from PP and PVC from Corsica seawaters and sediment were able to degrade LDPE. It was shown that as simultaneously to the biofilm formation, preliminary results showed a significantly LDPE weight loss of $3.5 \%+/-0.34$ after 80 days. The similar loss of weight was also observed in medium containing $0.05 \%$ of yeast extract and LDPE as main carbon source after 80 days. Moreover, the apparition of oxidative peaks in ATR-FTIR spectra after 80 days confirms degradations of LDPE by isolated Alcanovirax borkumensis. The biodegradation observation was shown by SEM as in figure 4. Zettler (2013) reported that PP and PE collected from North Atlantic Subtropical Gyre showed signs of degradation including cracks and pitting when observed with SEM (Figure 5), ranged in size from sub-mm diameter monofilament. Bacteria assemblages including some recognized hydrocarbon degrading 
bacteria namely Phormidium sp., Pseudoalteromonas, Hyphomonadacea were identified in the cracked PP and PE. Unfortunately, the precise bacteria or consortia really played a role in the degradation, also the mechanisms of the degradation itself was still unclear. The plastics expose period to the sea water also remained unknown (Zettler, 2013)

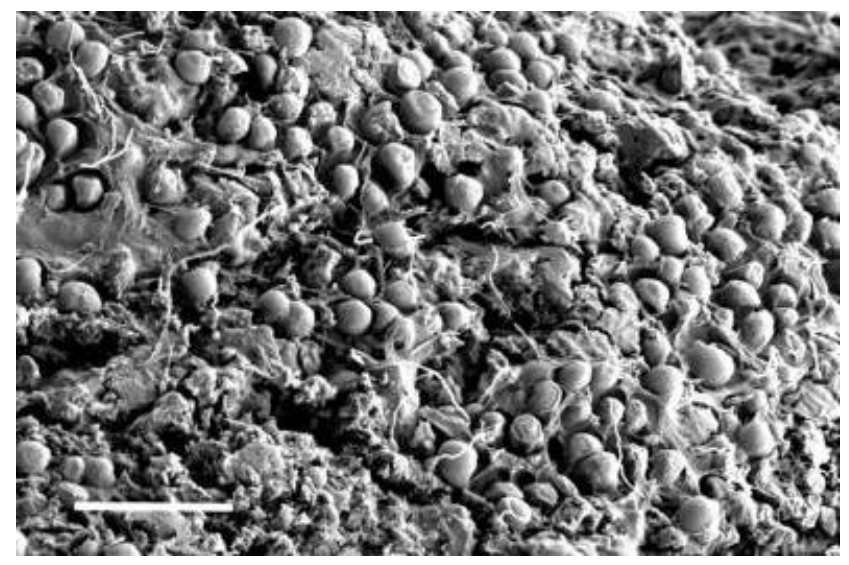

Figure 5. microbial cells pitting the surface of sample C241_12. All scale bars are $10 \mu \mathrm{m}$.

As previously mentioned, some studies also conducted researches about bacterias isolated from marine plastic debris or plastic that soaked to the seawaters (in situ) without further observation on visible bodegradation. These studies have identified the microorganism that have been recognized for its ability to degrade plastic, were attached to the plastic debris or the seawater soaked plastics (Table 2). Oberbeckmann et al. (2016) showed that PET drinking bottles submerged in North Sea off the UK coast were colonized by bacteria which were recognized to degrade plastics, such as Rhodobacteraceae and Alcanivoraceae. Interestingly, Alcanivoraceae in this study was only found in the PET bottle, but not in surrounding seawater, nor in the glass microscope slides that were also submerged in the area (Oberbeckmann, 2016). The preference of the Alcanivoraceae to the PET showed that it might be attached to the PET due to PET composition of hydrocarbon chain. Dellacuvellerie (2019) also found that Pseudomonas genus presented in PS sample after enrichment test has been carried out. The enrichment test used PS as the main carbon source. The bacteria source were isolated from PE floated in Corsica sea waters. Several Pseudomonas species are known for their ability to degrade polystyrene. Unfortunately, the further observation regarding biodegradation in this test was not possible because PS negative control has been cracked and had irregular shape already (Dellacuvellerie, 2019).

Bacteria can exist under unfavorable conditions (Urbanek et al, 2018). Therefore, microbial communities resistant to such conditions may show many unique features. It was shown that in seawater, plastic releases dissolved organic carbon, stimulating the activity of heterotrophic microbes (Romera-Castillo et al. 2018). Despite these facts, we still lack of information about the biodegradation possibility of petrochemical plastic such as PCV or PET in marine environment Thus, it clearly shows that we still lack full information about the microbial potential for plastic degradation in marine environment (Urbanek et al. 2018),

\section{Potentials of using bacteria in degrading existing plastic waste in Jakarta Bay}

As described in latest part of previous sub chapter, information about microbial potential for plastic degradation in marine environment globally are still very limited (Urbanek et al. 2018; Sheth et al. 2019), let alone if the location is narrowed down to Jakarta Bay only. So far, no reports showed study on microorganisms or bacteria isolated from Jakarta Bay plastic debris and Jakarta Bay waters, nor from plastic debris of other Indonesian region marine environment. Study about identifiying microbial communities sampled from plastic debris in Jakarta Bay and how they interact with the plastic debris is urgently needed to take further investigation about their ability to degrade highly accumulated existing plastic waste (Urbanek et al. 2018).

However, the potential is likely there, as Sheth, et al. (2019) suggested two key habitats to identify plasticbiodegrading organisms, namely: (1) habitats with distinct enrichment of plastic waste, such as those near processing or disposal sites, and (2) habitats with naturally occurring polymers, such as cutin, lignin, and wax. High plastic waste concentrations area may exert eco-toxicological selective pressures, leading to the evolution of biodegradation mechanisms as a means to utilize plastic as an additional carbon source. Plastic enriched sites yield also promising prospects in the form of bacterial consortia. Skariyachan et al (2017) and Shah et al (2016) suggested that indigenous consortia could maximize the potential for degradation, if compared to single microbial species or strains (Sheth et al, 2019). This might be happened because generally depolymerization of polymer chains into monomers requires several different microorganisms. For example, a bacterium is able to break down a polymer into oligomer, another bacterium will break down oligomer into a monomer, then another bacterium is able to use a monomer and secrete a simpler compound. Other bacteria can even use these excreted compounds (Fachrul and Rinanti, 2018)

Sheth, et al. (2019) also suggested that marine environment was included in habitats with naturally occuring polymers. Marine environment is an uncharted ecosystem enriched with microbial biodiversity (Sogin et al. 2006; Sheth et al, 2019) and naturally occurring polymers like cross-linked proteins in mussels and sea cucumbers (Scott 2015; Sheth et al. 2019), in addition to anthropogenic hydrocarbons like plastic waste and petroleum (National Research Council 2003; Chiba et al. 2018). These two characteristics are fit to Jakarta Bay 
characteristics, which is also home for several bivalves including green mussel (Nuraini et. al, 2011; Kusnoputranto et al, 2014) and is vulnerable to plastic waste and oil spill problems (Darmayati, 2009; Dwinovantyo et al. 2016).

While most of research about plastic biodegrading organisms, including in Indonesia, have been isolated from soil and dumpsite (Sheth et al, 2019; Elpawati, 2015; Ainiyah and Shovitri, 2014; Sriningsih and Ainiyah, 2015; Octavianda 2016; Fachrul and Rinanti, 2018), the potentials of bacterias isolated from Jakarta Bay plastic pollutants in degrading plastic should be explored. In the other hand, research about oil spill degrading bacteria isolated from Jakarta Bay has been carried out and explored by some researchers already (Darmayati, 2009; Sutiknowati 2011, Alfiansah et al, 2014; Dwinovantyo et al, 2016). The possibility of oil spill degrading bacteria in degrading plastic waste, can also be studied. In addition, it can be compared to the bacteria communities isolated from plastic waste, in terms of genera, species or characteristics. A study showed that marine bacteria that exclusively feed on hydrocarbons have been found to degrade oil spills. This behavior suggested that they could adapt to other manmade hydrocarbons like plastic as well (Brooijmans et al. 2009; Sheth et al, 2019). Interestingly, this paper finds the theory could be true. A research about oil spill biodegradation has identified Alcanivorax borkumensis in Pari Island seawaters, which connected to Jakarta Bay waters. While Alcanivorax borkumensis sampled in Corsica sea waters has been proven to degrade LDPE (Delacuvellerie, 2019) in previous sub chapter of this paper, Alcanivorax borkumensis identified in Pari Island seawaters has been shown to degrade oil spill (Sutiknowati 2011). PE was also found to dominate the existing plastic debris in Jakarta Bay, in which, this finding could offer the potential solution in solving Jakarta Bay existing plastic waste using bacteria.

\section{Challenges of using bacteria in degrading existing plastic waste in Jakarta Bay and future research direction}

Another challenge about plastic biodegradation, apart from still limited information and research about this topic, is how to apply it without any environmentally adverse byproducts. The first important step is, to conduct a research to identify the bacteria isolated from Jakarta Bay plastic debris to know which bacterias are highly attrated to specific plastic type. Subsequent research can be carried out about which one more effective in degrading marine plastic waste, single bacteria, indigeneous consortia, or tailored consortia (Syranidou, 2019) after bacterias interested and survived in Jakarta Bay plastic waste are identified. The next step is to do the genetical engineering to speed up and boost the effectiveness of bacteria capability in degrading plastic with environmentally friendly byproducts.
Recently, wax worm Galleria mellonella was reportedly able to degrade PE (Bombelli et al. 2017). Holes in PE started to appear after 40 minutes, with an estimated $2.2 \pm 1.2$ holes per worm per hour. The result was 100 wax worms in contact with a commercial PE shopping bag for more or less 12 hours caused a PE mass loss of $92 \mathrm{mg}$. To eliminate the possibility of mechanical action of the masticatory system was solely responsible for the breakdown, Bombelli et al (2017) analyze further with the effect of wax worm homogenate on the PE surface. Atomic Force Microscopy (AFM) was performed. After treatment with homogenate, obvious change in the topography of the PE surface was found, corresponding to a significant (one-way ANOVA $=0.005$ ) greater than $140 \%$ increase in surface roughness. These results indicate that the physical contact of the wax worm homogenate with the PE surface modified the integrity of the polymer surface. The appearance of holes when PE films are left in direct contact with wax worms, and the FTIR analysis of degraded $\mathrm{PE}$, indicate chemical breakdown of the PE, including breakage of $\mathrm{C}-\mathrm{C}$ bonds. It is still not clear whether the hydrocarbon-digesting activity of $G$. mellonella derived from the organism itself, or from enzymatic activities of its intestinal flora. It was expected that this ability was caused by the ecology of the wax worm itself. They feed on beeswax, and their natural niche is the honeycomb. The moth lays its eggs inside the beehive, where the worms grow to their pupa stage, eating beeswax. Beeswax is composed of a highly diverse mixture of lipid compounds, including alkanes, alkenes, fatty acids and esters. The most frequent hydrocarbon bond is the $\mathrm{CH} 2-\mathrm{CH} 2$, as in PE (Bombelli et al, 2017). If the enzymes responsible for this ability are found, the sequence coding could be expressed to the designated bacteria, such as identified abundant bacteria in Jakarta Bay plastic debris, or indigenous bacteria from Jakarta Bay waters, to speed up and boost the bacteria ability to degrade plastic debris.

Although new approach using bacteria for marine plastic pollutants biodegradation is still need many studies and development, even in global scale, there is still an urgency to at least, to start the research about identifying bacteria isolated from plastic debris in Jakarta Bay. While 3R program should be more encouraged to minimize the upcoming plastic waste, it is needed as mitigation measure to save Jakarta Bay ecosystem and biodiversity from highly accumulated existing plastic waste.

\section{REFERENCES}

Ainiyah DN, \& Shovitri M. 2014. Bakteri tanah sampah pendegradasi plastik dalam kolom winogradsky. J. Sains Dan Seni Pomits, 3(2), E63-E66.

Alfiansah Y, Adindasari M, Argarini M, Darmayati Y, \& Ruyitno, -. 2015. Isolation and distribution of crude oil and polycyclic 
aromatic hydrocarbon-degrading bacteria from polluted harbours in North Jakarta. Mar. Res. in Indonesia 39(2): 7985.

Arifin Z. 2004. Local Millenium Ecosystem Assessment: Condition and Trend of The Greater Jakarta Bay Ecosytem. The Ministry of Environment, Republic of Indonesia, Jakarta.

Artham T, Sudhakar M, Venkatesan R, Madhavan Nair C, Murty KVG, Doble M. 2009. Biofouling and stability of synthetic polymers in sea water. Int. Biodeterior. Biodegradation 63:884-890

Asia -, Arifin, MZ. 2017. Dampak sampah plastik bagi ekosistem laut. Bul. Matric 14 (1). 44-48

Atmaja, SB. 2011. Upaya Menuju Pengelolaan Perikanan Berkelanjutan: Fragmentasi Habitat Teluk Jakarta dan Kepulauan Seribu. In: Ali S., Wudianto, Bambang S. (eds) Sumber Daya Ikan Di Perairan Teluk Jakarta dan Aternatif Pengelolaannya. Penerbit IPB Press, Bogor.

BAPEKAB-Kepulauan Seribu. 2002. Data Saku Kabupaten Administrasi Kepulauan Seribu. Proyek Perencanaan Pengembangan Wilayah Kepulauan Seribu.

Balai Taman Nasional Kepulauan Seribu (BTNKpS). 2011. Review Rencana Pengelolaan Taman Nasional (RPTN) Kepulauan Seribu Periode Tahun 1999 s/d 2019. Kabupaten Administrasi Kepulauan Seribu Provinsi DKI Jakarta, Jakarta.

Bombelli P, Howie CJ, Bertocchini F. 2017. Polyethylene biodegradation by caterpillars of the wax moth Galleria mellonella. Curr. Biol. 27(8): R292-R293. DOI: 10.1016/j.cub.2017.02.060.

Bryant JA, Clemente TM, Viviani DA, et al. 2016. Diversity and activity of communities inhabiting plastic debris in the North Pacific Gyre. mSystems 1(3): e00024-e00016

Brooijmans RJ, Pastink MI, and Siezen RJ. 2009. Hydrocarbondegrading bacteria: the oil-spill clean-up crew. Microb. Biotechnol. 2: 587-594. DOI: 10.1111/j.17517915.2009.00151.x

Caruso, G. 2015. Plastic degrading microorganisms as a tool for bioremediation of plastic contamination in aquatic environments. J. Pollut. Eff. Cont. 3: e112.

Chiba S, Saito H, Fletcher R, et al. 2018. Human footprint in the abyss: 30 year records of deep-sea plastic debris. Mar. Policy 96: 204-212. DOI: 10.1016/j.marpol.2018.03.022.

Dash HR, Mangwani N, Chakraborty J, et al. 2013. Marine bacteria: potential candidates for enhanced bioremediation. Appl. Microbiol. Biotechnol. 97(2): 561-571.

Darmayati Y. 2009. Development of oil bioremediation research on marine environment in Indonesia. J. of Coast Development 12 (3): $105-11$

De Tender CA, Devriese LI, Haegeman A, et al. 2015. Bacterial community profiling of plastic litter in the Belgian part of the North Sea. Environ. Sci. Technol. 49(16): 9629-9638

Debroas D, Mone A, Ter Halle A. 2017. Plastics in the North Atlantic garbage patch: a boat-microbe for hitchhikers and plastic degraders. Sci Total Environ. 599-600:1222-1232

Dellacuvellerie A, Cyriaque V, Gobert S, et al. 2019. The plastisphere in marine ecosystem hosts potential specific microbial degraders including Alcanivorax borkumensis as a key player for the lowdensity polyethylene degradation. J. of Hazard. Mater. 380: 120899.

Derraik JG. 2002.The pollution of the marine environment by plastic debris: a review. Mar Pollut Bull 44(9): 842-852.
Dussud C, and Ghiglione, J.-F. 2014. Bacterial degradation of synthetic plastics. In: F. Briand (ed) Marine Litter in the Mediterranean and Black Seas, CIESM Publisher, Paris.

Dwinovantyo A, Susanti S, Prabowo NW, et al. 2016. Oil spill biodegradation by bacteria isolated from Jakarta Bay marine sediments. Ilmu Kelaut: Indonesian J. of Mar. Sci. 21(1): 2936.

Dwiyitno,-.,Wibowo S, Januar HI, et al. 2018. Ancaman Cemaran Marine Debris dan Mikroplastik pada Lingkungan Perairan dan Produk Perikanan. Policy Brief No. PB04-4-2018. Balai Besar Riset Pengolahan Produk dan Bioteknologi Kelautan dan Perikanan, Jakarta.

Eich A, Mildenberger T, Laforsch C, Weber M. 2015. Biofilm and diatom succession on polyethylene (PE) and biodegradable plastic bags in two marine habitats: early signs of degradation in the pelagic and benthic zone? PLoS One 10(9): e0137201

Elpawati. 2015. Uji Coba Produksi Mikroorganisme Pendegradasi (Penghancur) Sampah Plastik. Jurnal Agribisnis 9(1): 11-22.

Estradivari, E. Setyawan \& S. Yusri. 2009. Terumbu Karang Jakarta: Pengamatan Jangka Panjang Terumbu Karang Kepulauan Seribu (2003-2007). Yayasan TERANGI, Jakarta.

Fachrul MF, Rinanti A. 2018. Bioremediation of Microplastic Pollutant in Aquatic Ecosystem by Indigenous Bacteria. In: Rinanti A (ed) Pros. Semin. Nas. Kota Berkelanjutan. Trisakti University, Jakarta, 3 Mei 2017. [Indonesian]. DOI: 10.25105/psnkb.v1i1.2910

Harrison P, Sapp M, Schratzberger M, Osborn AM. 2011. Interactions between microorganisms and marine microplastics: a call for research. Mar. Technol. Soc. J 45(2):12-20.

Hidayat, A. 2018, August 24. Pemerintah DKI Kewalahan Tangani Sampah di Teluk Jakarta. Tempo. Retrieved from https://fokus.tempo.co/read/1120043/pemerintah-dkikewalahan-tangani-sampah-di-teluk-jakarta/full\&view=ok

Harshvardhan K, and Jha, B. 2013. Biodegradation of low-density polyethylene by marine bacteria from pelagic waters, Arabian Sea, India. Mar. Pollut. Bull. 77: 100-106. DOI: 10.1016/j.marpolbul.2013.10.025

Ipekoglu B, Böke H, and Çizer, Ö. 2007. Assessment of material use in relation to climate in historical buildings. Build. Environ. 42: 970-978. DOI: 10.1016/j.buildenv.2005.10.029

Jacquin J, Cheng J, Odobel C, et al. 2019. Microbial Ecotoxicology of Marine Plastic Debris: A Review on Colonization and Biodegradation by the "Plastisphere". Front. Microbiol. 10:865. DOI: 10.3389/fmicb.2019.00865.

Jambeck JR, Geyer R, Wilcox C, Siegler TR, Perryman M, Andrady A, Narayan R, Law KL. 2015. Plastic waste inputs from land into the ocean. Science 347:768-771. DOI: $10.1126 /$ science. 1260352 .

Junge K, Eicken H, Deming JW. 2004. Bacterial activity at -2 to -20 degrees $C$ in Arctic wintertime sea ice. Appl. Environ. Microbiol. 70(1): 550-557.

Kusnoputranto H, Moersidik SS,Wisnubroto DS, et al. 2014. Accumulation and Depuration of PSP Toxin (Paralytic Shellfish Poisoning) by Green Mussels. Ilmu Kelaut: Indonesian J. of Mar. Sci. 19(1): 27-34.

Lobelle D, Cunliffe M. 2011. Early microbial biofilm formation on marine plastic debris. Mar. Pollut. Bull. 62(1):197-200.

Lotulung GA. 2018, December 10. Sampah yang menumpuk di kawasan Teluk Jakarta, Muara Angke, Jakarta Utara, Rabu (14/3/2018). Kompas. Retrieved from https://asset.kompas.com/crops/yuVbef897i4LS7iqHQDIcv8s 
$\mathrm{KM}=/ 1 \times 2: 1000 \times 668 / 750 \times 500 /$ data/photo/2018/03/15/2919273 420.jpg

Mabrouk MM, and Sabry SA. 2001. Degradation of poly (3hydroxybutyrate) and its copolymer poly (3-hydroxybutyrateco-3-hydroxyvalerate) by a marine Streptomyces sp. SNG9. Microbiol. Res. 156: 323-335. DOI: 10.1078/0944-501300115.

Maharani A, Handyman DI, Salafy A, et al. 2017. Macro Debris Condition in Mangrove Untung Java Island, Kepulauan Seribu. In: Windiastuti W, Oktaviani N, Oktaviani M, et al. (eds) Pros. Semin. Nas. Geomat. 2017: Inov. Teknol. Penyediaan Inf. Geospasial untuk Pembang. Berkelanjutan. Badan Informasi Geospasial, Cibinong, 14 November 2017. [Indonesian].

Martínez-Tobón DI, Gul M, Elias AL, Sauvageau, D. 2018. Polyhydroxybutyrate (PHB) biodegradation using bacterial strains with demonstrated and predicted PHB depolymerase activity. Appl. Microbiol. Biotechnol. 102: 8049-8067. DOI: 10.1007/s00253-018-9153-8.

Mohee R, Unmar GD, Mudhoo A, et al. 2008. Biodegradability of biodegradable/degradable plastic materials under aerobic and anaerobic conditions. Waste Manag. 28: 1624-1629. DOI: 10.1016/j.wasman.2007.07.003

Nastiti AS, Putri MRA, Hartati, ST. 2011. Kajian Kawasan Konservasi Daerah Asuhan Udang di Teluk Jakarta. In: Ali S., Wudianto, Bambang S. (eds) Sumber Daya Ikan Di Perairan Teluk Jakarta dan Aternatif Pengelolaannya. Penerbit IPB Press, Bogor.

National Oceanic and Atmospheric Administration Marine Debris Program. 2014. Report on the Entanglement of Marine Species in Marine Debris with an Emphasis on Species in the United States. Silver Spring, Maryland.

National Oceanic and Atmospheric Administration. 2016. Modeling oceanic transport of floating marine debris. Silver Spring, Maryland: 21.

National Research Council. 2003. Oil in the Sea III: Inputs, Fates, and Effects. National Academies Press, Washington DC.

Nuraini S, Prihatiningsih, Wahyuningsih, Wejatmiko. 2011. Status Pemanfaatan Kekerangan di Perairan Teluk Jakarta dan Sekitarnya. In: Ali S., Wudianto, Bambang S. (eds) Sumber Daya Ikan Di Perairan Teluk Jakarta dan Aternatif Pengelolaannya. Penerbit IPB Press, Bogor.

Oberbeckmann S, Osborn AM, Duhaime MB. 2016. Microbes on a bottle: substrate, season and geography influence community composition of microbes colonizing marine plastic debris. PLoS One 11(8): e0159289.

Oberbeckmann S, Kreikemeyer B, Labrenz M. 2017. Environmental factors support the formation of specific bacterial assemblages on microplastics. Front. Microbiol. 8:2709.

Octavianda FT, Asri MT, Lisdiana L. 2016. Potential of OxoDegradable Polyethylene-Degrading Bacteria of Benowo Landfill Soil Surabaya. Lentera Bio Berkah Ilmiah Biologi $5(1)$.

jurnalmahasiswa.unesa.ac.id/index.php/lenterabio/article/view /14560 [1 September 2019]

O'Brine T, Thompson RC. 2010. Degradation of plastic carrier bags inn the marine environment. Mar. Pollut. Bull. 60(12):2279-2283.

Pauli NC, Petermann JS, Lott C,Weber M. 2017. Macrofouling communities and the degradation of plastic bags in the sea: an in situ experiment. R. Soc. Open Sci. 4(10):170549.
Rachmat SLJ, Purba NP, Agung MUK, et al. 2018. Characteristic of microplastic debris at estuary of DKI Jakarta. Depik J. Ilmu-Ilmu Perair., Pesisir dan Perikan. (8)1: 9-17.

Ramadhan, A. 2018, December 10. LIPI Sebut 21 Ton Sampah Masuk ke Teluk Jakarta Tiap Harinya. Kompas. Retrieved from

https://megapolitan.kompas.com/read/2018/12/10/15413661/li pi-sebut-21-ton-sampah-masuk-ke-teluk-jakarta-tiap-harinya.

Raghul SS, Bhat SG, Chandrasekaran M, et al. 2014. Biodegradation of polyvinyl alcohol-low linear density polyethylene-blended plastic film by consortium of marine benthic vibrios. Int. J. Environ. Sci Technol. 11(7):1827-1834.

Romera-Castillo C, Pinto M, Langer TM, et al. 2018. Dissolved organic carbon leaching from plastics stimulates microbial activity in the ocean. Nat. Commun. 9(1):1430.

Rositasari R, Puspitasari R, Nurhati IS, et al. 2017. 5 Dekade LIPI di Teluk Jakarta Review Penelitian Oseanografi di Teluk Jakarta 1970 - 2015. Pusat Penelitian Oseanografi - Lembaga Ilmu Pengetahuan Indonesia, Jakarta.

Rummel CD, Jahnke A, Gorokhova E, Kühnel D, Schmitt-Jansen M. 2017. Impacts of biofilm formation on the fate and potential effects of microplastic in the aquatic environment. Environ. Sci. Technol. Lett. 4(17):258-267.

Scott AR. 2015. Polymers: secrets from the deep sea. Nature 519: S12-S13.

Sekiguchi T, Sato T, Enoki M, Kanehiro H, Uematsu K, Kato C. 2010. Isolation and characterization of biodegradable plastic degrading bacteria from deep-sea environments. Jamstec-R 11:33-41

Sekiguchi T, Saika A, Nomura K, et al. 2011. Biodegradation of aliphatic polyesters soaked in deep seawaters and isolation of poly( $\varepsilon$-caprolactone)-degrading bacteria. Polym. Degrad. Stab. 96(7):1397-1403

Shah AA, Hasan F, Hameed A, et al. 2008. Biological degradation of plastics: a comprehensive review. Biotechnol. Adv. 26: 246-265. DOI: 10.1016/j.biotechadv.2007.12.005.

Shah Z, Gulzar M, Hasan F, et al. 2016. Degradation of polyester polyurethane by an indigenously developed consortium of Pseudomonas and Bacillus species isolated from soil. Poly. Degrad. Stab. 134: 349-356. DOI: 10.1016/j.polymdegradstab.2016.11.003.

Sheth MU, Kwartler SK, Schmaltz ER, et al. 2019. Bioengineering a Future Free of Marine Plastic Waste. Front. Mar. Sci. 6:624. DOI: 10.3389/fmars.2019.00624

Skariyachan S, Setlur AS, Naik SY, et al. 2017. Enhanced biodegradation of low and high-density polyethylene by novel bacterial consortia formulated from plastic-contaminated cow dung under thermophilic conditions. Environ. Sci. Pollut. Res. Int. 24, 8443-8457. DOI: 10.1007/s11356-017-8537-0.

Sogin, ML, Morrison HG, Huber JA, et al. 2006. Microbial diversity in the deep sea and the underexplored "rare biosphere". Proc. Natl. Acad. Sci. USA. 103:12115. DOI: 10.1073/pnas.0605127103.

Suhery N, Damar A, Effendi H. 2017. Coral reef ecosystem vulnerability index to oil spill: case of Pramuka Island and Belanda Island in Seribu Islands. J Ilmu dan Teknol. Kelaut. Tropis 9 (1): 67-90.

Sumiono B, Wagiyo K, Kembaren D, et al. 2011. Aspek penangkapan dan biologi Rajungan (Portunus pelagicus Linn) di Perairan Teluk Jakarta. In: Ali S., Wudianto, Bambang S. (eds) Sumber Daya Ikan Di Perairan Teluk Jakarta dan Aternatif Pengelolaannya. Penerbit IPB Press, Bogor. 
Sundt P, Schulze PE, Syversen F. 2014. Source of MicroplasticsPollution to The Marine Environment. Mepex, Norway.

Sutiknowati LI. 2011. Microbial Community During Bioremendiation Experimental On Oil Spill in Coastal of Pari Island. J. Ilmu Kelaut. Tropis 3(1): 91-103.

Suraji -, Rasyid N, Kenyo AS, et al. 2015. Profil Kawasan Konservasi Provinsi DKI Jakarta. Direktorat Konservasi Kawasan dan Jenis IkanDirektorat Jenderal Kelautan, Pesisir dan Pulau-Pulau Kecil Kementerian Kelautan dan Perikanan, Jakarta.

Syranidou E, Karkanorachaki K, Amorotti F, et al. 2019. Biodegradation of mixture of plastic films by tailored marine consortia. J. Of Hazard. Mater. 375: 33-42.

UNEP. 2011. Emerging Issues in Our Global Environment. United Nations Environment Programme, Nairobi.

Urbanek AK, Rymowicz W, Mironczuk AM. 2018. Degradation of plastics and plastic-degrading bacteria in cold marine habitats. Appl. Microbiol. and Biotechnol 102: 7669-7678.

Uefuji M, Kasuya K, and Doi Y. 1997. Enzymatic degradation of poly[(R)-3-hydroxybutyrate]: secretion and properties of PHB depolymerase from Pseudomonas stutzeri. Polym. Degrad. Stab. 58: 275-281. DOI: 10.1016/S0141-3910(97)00058-X.

van Sebille E, Spathi C, Gilbert A. 2016. The ocean plastic pollution challenge: towards solutions in the UK. Grantham Briefing Papers: 19

Wardiatno Y, Irfangi C, Hesti-rianoto T. 2010. Dolphins encountered in Kepulauan Seribu. Ilmu Kelaut. 15(4): 202213.

Williams TM, Rees JG, Setiapermana D. 2000. Metals and trace organic compounds in sediments and waters of Jakarta Bay and the Pulau Seribu complex, Indonesia. Mar. Poll. Bull. 40(3): 277-285.

Zettler ER, Mincer TJ, Amaral-Zettler LA. 2013. Life in the "plastisphere": microbial communities on plastic marine debris. Environ. Sci. Technol. 47(13):7137-7146.

Zuraya, N. 2018, November 28. Tiga Penyu Mati di Pulau Pari Diduga Akibat Sampah Plastik. Republika. Retrieved from https://www.republika.co.id/berita/nasional/umum/18/11/28/pi vy2q383-tiga-penyu-mati-di-pulau-pari-diduga-akibatsampah-plastik. 
THIS PAGE INTENTIONALLY LEFT BLANK 